\title{
PARTICULARITIES OF HYDRAULIC CALCULATION OF COLLECTING PREASSURE DRAINAGE PIPELINES
}

\author{
Kravchuk O.A., PhD, Associate Professor, \\ kravchuk.oa2@knuba.edu.ua, ORCID:0000-0001-6578-8896 \\ Kyiv National University of Construction and Architecture \\ 31, Povitroflotsky Ave., Kyiv, 03037, Ukraine
}

\begin{abstract}
A system of two differential equations, which describes the fluid motion in a pipe with a variable flow rate and the conditions for fluid entry through the drainage pipelines walls from the surrounding soil, is considered. It is shown that for the studied case the second term in the original equation can be neglected without a significant error. The system is reduced to a dimensionless form by introducing the original variables. The solution of this equations system is given in a dimensionless form.

Two main parameters are used in the analysis: the coefficient of collecting drainage pipeline resistance " $\zeta_{l}$ " and the generalized parameter " $A$ ", which takes into account the structural and hydraulic characteristics of the considered flow. Also, the concept of an infinitely long drainage pipeline or, which is the same, a pipeline with an infinite walls filtration capacity of the drainage pipeline is introduced in the article. It is noted that such pipeline will have a maximum throughput compared to pipes of the same diameter but limited length. Sufficiently simple and convenient calculated dependencies for the determination of the nature of flow rate variation and pressure drop along the length of the pipeline were obtained on the basis of the conducted analysis.

Series of calculations of important characteristics for such pipes were carried out on the basis of offered formulas. Corresponding graphical dependencies were built for visibility. In particular, graphs of the flow rate variations at the end of the collector, depending on the design and filtration characteristics of the "soil-drain" system, are presented. Graph, that shows the dependence of the change in the flow rate connection unevenness along the length of the drainage pipeline at various hydraulic conductivity values of the surrounding soil, is important for understanding the drainage pipes particularity. The necessity to take into account the nature of the flow rate connection unevenness along the length for obtaining reliable results when calculating real drainage pipelines is shown in the article.
\end{abstract}

Keywords: perforated pipeline, drainage pipeline, hydraulic friction factor, hydraulic conductivity, filtration resistance, drain, variable fluid flow.

Introduction. Pressure drainage pipelines serve as important structural components of the reclamation complex systems in many cases [1]. They are used in particular to ensure the required water regime of rice systems when washing pipelines and land, discharge excess water through drains during floods and others. Such systems operation modes are considered the most difficult in their exploitation and calculation [2]. In this case the drainage pipelines work in full cross-section with a continuous, usually uneven, liquid connection along its length [3]. A reliable determination of the design and filtration characteristics of such pipes will accordingly ensure reliable and efficient operation of the entire system.

The peculiarity of these pipelines is that the fluid flow parameters in them are affected by the design of the drainage pipes, the filtration characteristics of the surrounding soil, the groundwater level and the distance between the drains. It is difficult to single out the effect of each of these parameters on the intensity of fluid flow into the drains. Therefore, they are usually taken into account comprehensively by introducing a special filtration resistance of the "soil-drain" system. The scheme of such pipelines operation is presented in Fig. 1.

Bulletin of Odessa State Academy of Civil Engineering and Architecture, 2021, no. 83, page 130-138 


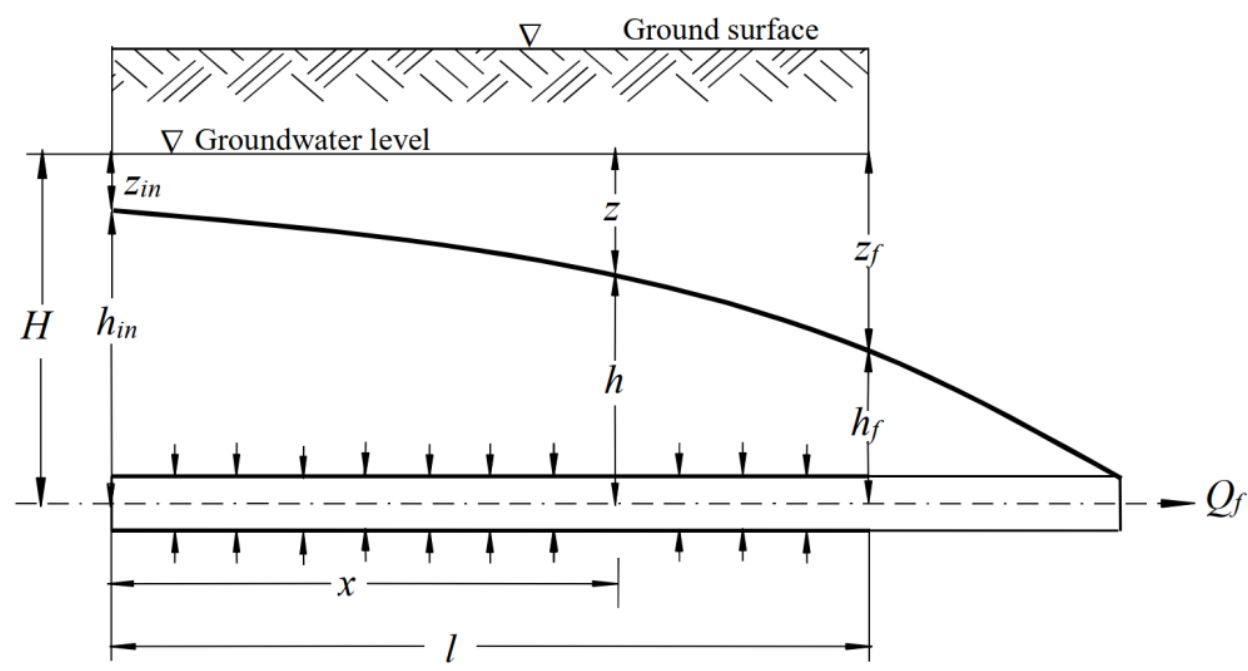

Fig. 1. Scheme of the pressure collecting drainage pipeline operation

Analysis of the latest achievements and publications. Many domestic and foreign scientists have dealt with the problem of developing a method of collecting drainage pipelines hydraulic calculation for reclamation systems. Among them are such authors as Petrov G.A. [4], Dmitriev A.F., Pivovar N.G. [5], Mayboroda V.O. [6], Murashko A.I. [7], Oleynik O.Ya., Poliakov V.L. [2]. Fluid motion in perforated pipelines, as is well known, occurs at a variable flow rate along the path. Therefore, the vast majority of authors used the equation of fluid motion with variable mass as the initial mathematical dependences in solving this issue. However, almost all the researchers have used some assumptions and approximations in solving this issue due to its complexity. And it has not yet allowed to obtain a reliable result.

The purpose of this work is to develop and propose for practical application a reliable method of pressure perforated pipelines hydraulic calculation for reclamation systems, that operate with the liquid connection along the path in the filtration mode. Particular attention is paid to the definition and consideration of patterns of flow rate variation along the pipelines length.

Research methodology. The presented research materials are based on the results of personal analytical researches of the basic mathematical dependences, which describe the motion of a pressure liquid stream in perforated pipelines.

Research results. Fluid motion in a single pressure drainage pipeline operating without transit, as is well known, is described by a system of differential equations. It consists of the variable mass hydraulics equation (1) and the modified filtration equation (2) $[4,6,8]$ :

$$
\begin{gathered}
\frac{d h}{d x}+\frac{2}{g} V \frac{d V}{d x}+\frac{\lambda_{c o l}}{2 g D} V^{2}=0, \\
\frac{d(V \Omega)}{d x}=\frac{k(H-h)}{\bar{\Phi}}=k \frac{z}{\bar{\Phi}},
\end{gathered}
$$

where $H$ is the depth of immersion of the pipeline axis from the groundwater level; $h$ - piezometric head in the pipe; $z=H-h$ is variable head drop along the length, under which action a liquid inflow from the environment into the pipeline is taking place; $Q, V, D, \Omega$ are, respectively, the flow rate, average velocity, diameter, and free cross-sectional area of the flow at the distance $x$ from the beginning of the pipe; $\bar{\Phi}$ is dimensionless drain filtration resistance (its definition is a separate filtration problem [2]); $k$ is soil hydraulic conductivity around the pipe; $\lambda_{c o l}$ is hydraulic friction factor of collecting drainage pipeline [9]; $g$ is gravitational acceleration.

It is conventionally assumed that the liquid inflow into the pipeline is carried out through the entire side surface of the collector and the layer of surrounding filtration material continuously in the analysis of mathematical models (1), (2). The mode of the liquid motion in the drain is considered turbulent, and its inflow from the environment through the side walls is carried out in the filtration mode. The filtration resistance of the "soil-drain" system $\bar{\Phi}$ and the hydraulic friction 
factor $\lambda_{c o l}$ are assumed to be constant along the pipeline and equal to their average value along the length. The angle, at which the liquid is connected to the main flow in the pipeline, is also constant and equal $\pi / 2$ [10]. Leakage of liquid from the drainage pipe can be carried out both in the atmosphere $\left(h_{f}=0\right)$ and below the water level $\left(h_{f} \neq 0\right)$ in its final section.

After entering new variables:

$$
\bar{V}=\frac{V}{\sqrt{g z_{f}}}, \quad \bar{x}=\frac{k x}{\Omega \bar{\Phi}} \sqrt{\frac{z_{f}}{g}}, \quad \bar{z}=\frac{z}{z_{f}}, \quad d h=-z_{f} d \bar{z},
$$

the system of equations (1), (2) is reduced to a dimensionless form:

$$
\begin{gathered}
-\frac{d \bar{z}}{d \bar{x}}+2 \bar{V} \frac{d \bar{V}}{d \bar{x}}+\zeta_{l_{d r}} A \bar{V}^{2}=0, \\
\frac{d \bar{V}}{d \bar{x}}=\bar{z},
\end{gathered}
$$

where $\zeta_{l_{c o l}}=\lambda_{c o l} \frac{l}{D}$ is the coefficient of collecting drainage pipeline resistance; $A=\frac{1}{2 \bar{x}_{f}}=\frac{\Omega \bar{\Phi}}{2 k l} \sqrt{\frac{g}{z_{f}}}$ is generalized parameter of collecting drain, which takes into account its design and filtration characteristics.

The second term of equation (4) indicates the head loss, associated with the effect of fluid accession. The third term indicates the hydraulic friction loss along the length.

The second term in equation (4) can be neglected without a significant error for collecting pipelines with a turbulent regime of fluid connection along the path through the holes and slits at their relative length $\left(\zeta_{l}>12\right)$, as shown in [11]. The intensity of mixing of the connected liquid volumes with the main flow is relatively small for drainage pipes with the liquid connection in the filtration mode.

The second term can be neglected in comparison with the third in equation (4), considering that the mentioned drainage pipes length is $\zeta_{l}>>12$. Then the equation (4) take the form:

$$
\frac{d \bar{z}}{d \bar{x}}=\zeta_{l_{d r}} A \bar{V}^{2} \text {. }
$$

After substituting (5) into (6) and dividing the variables, the obtained equation is:

$$
\bar{z} d \bar{z}=\zeta_{l_{d r}} A \bar{V}^{2} d \bar{V} \text {. }
$$

According to [12], its solution is:

$$
\frac{\bar{z}^{2}}{2}=\zeta_{l_{d r}} A \frac{\bar{V}^{3}}{3}+C
$$

The integration constant is found from the boundary conditions at the beginning of the pipe: $\bar{V}_{\text {in }}=0 ; \bar{z}=\bar{z}_{\text {in }}$ i $C=\bar{z}_{\text {in }}^{2} / 2$.

Then the relationship between the relative velocity and the current relative head drop in arbitrary and finite cross-sections respectively will be:

$$
\bar{V}=\sqrt[3]{\frac{3}{2 \zeta_{l_{d r}} A}\left(\bar{z}^{2}-\bar{z}_{i n}^{2}\right)}, \quad \bar{V}_{f}=\sqrt[3]{\frac{3}{2 \zeta_{l_{d r}} A}\left(1-\bar{z}_{i n}^{2}\right)}
$$

The concept of conditional infinitely long collecting drainage pipeline is introduced for the further analysis. Obviously, such pipeline will have maximum throughput compared to other pipelines of the same diameter but finite length. It is denoted by $Q_{f \infty}$. The greater the length of the real concrete pipeline, the flow rate in its final cross-section $Q_{f}$ will be asymptotically close to $Q_{f \circ}$. In this case, the longer the pipeline is, the flow rate coming into it from the environment in the initial sections will be reduced. The relationship $(d Q / d x)_{i n} \rightarrow 0$ will take place in the context of 
conditional infinitely long collecting drainage pipeline in its initial sections. The head drop, under which impact the liquid flows in these sections, will also decrease and when $l \rightarrow \infty$ it will approach zero $\left(z_{\text {in }} \rightarrow 0\right.$, or $\bar{z}_{\text {in }} \rightarrow 0$ ).

In view of the above, the dependence (9) to determine the relative velocity in the final section of an infinitely long drainage pipeline will take the form:

$$
\bar{V}_{f \infty}=\sqrt[3]{\frac{3}{2 \zeta_{l_{d r}} A}}=\sqrt[3]{\frac{12 k}{\lambda \pi D \bar{\Phi}} \sqrt{\frac{z_{f}}{g}}}
$$

The latter dependence can also be interpreted as the relative velocity in the final cross-section of the limited length pipeline, but with an infinitely large filtering capacity value of its side walls.

After substituting the values of $\zeta_{l_{d r}}$ and $A$ in (10), we obtain the maximum possible velocity and flow rate values at the end of an infinitely long pipeline in the measurement units:

$$
V_{f \infty}=\sqrt[3]{\frac{12 k}{\lambda \pi D \bar{\Phi}} g z_{f}^{2}}, \quad Q_{f \infty}=\sqrt[3]{\frac{3 g \pi^{2}}{16} \frac{k D^{5} z_{f}^{2}}{\lambda_{c o l} \bar{\Phi}}} .
$$

The integration constant $C=\frac{1}{2}-\zeta_{l_{d r}} A \frac{\bar{V}_{f}^{3}}{3}$ is defined using the boundary conditions at the end of the pipe $\bar{V}=\bar{V}_{f} ; \bar{z}_{f}=1$ in the solution of equation (7).

Then, the dependence, that relates the relative velocity $\bar{V}$ and the relative head drop in the respective cross-sections of the pipeline $\bar{z}$, will be:

$$
\bar{z}=\sqrt{\frac{2 \zeta_{l_{d r}} A}{3} \bar{V}^{3}-\frac{2 \zeta_{l_{d r}} A}{3} \bar{V}_{f}^{3}+1}
$$

Substitution of $\bar{V}_{f}$ by $\bar{V}_{f \infty}$ from (10) in equation (12) provides the dependence of $\bar{V}$ on $\bar{z}$ along the length of the infinitely long collecting drainage pipeline:

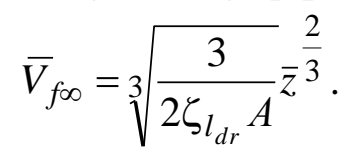

After differentiating expression (13), applying the substitution (5) and dividing the variables, the dependence (14) is obtained:

$$
\frac{3}{2} \sqrt[3]{\frac{2 \zeta_{l_{d r} A}}{3}} d \bar{x}=\bar{z}^{-\frac{4}{3}} d \bar{z}
$$

After integration it will be:

$$
\frac{3}{2} \sqrt[3]{\frac{2 \zeta_{l_{d r} A}}{3}} \bar{x}=-3 \bar{z}^{-\frac{1}{3}}+C
$$

The integration constant $C=3+\frac{3}{2} \sqrt[3]{\frac{2 \zeta_{l_{c o l} A}}{3}} \bar{x}_{f}$ is defined using the boundary conditions at the end of the pipe: $\bar{x}=\bar{x}_{f} ; \bar{z}_{f}=1$.

After its substitution in (15) and necessary transformations, the dependence (16) is finally obtained:

$$
\bar{z}=\frac{1}{\left[1+\frac{1}{2} \sqrt[3]{\frac{2 \zeta_{l_{c o l} A}}{3}}\left(\bar{x}_{f}-\bar{x}\right)\right]^{3}}=\frac{1}{\left[1+\frac{\bar{x}_{f}-\bar{x}}{2 \bar{V}_{f \infty}}\right]^{3}}=\frac{1}{\left(1+\frac{1-x / l}{4 A \bar{V}_{f \infty}}\right)^{3}}
$$


Then, at the beginning of the collector $\left(\bar{x}_{i n}=0\right)$ the relative head drop will be:

$$
\bar{z}_{i n}=\frac{1}{\left[1+\frac{\bar{x}_{f}}{2 \bar{V}_{f \infty}}\right]^{3}}=\frac{1}{\left[1+\frac{1}{4 A \bar{V}_{f \infty}}\right]^{3}} .
$$
obtained:

After $\bar{z}$ substitution from (5) to (16) and dividing the variables the expression (18) is

The integral of expression (18) will be [12]:

$$
d \bar{V}=\frac{d \bar{x}}{\left(1+\frac{\bar{x}_{\kappa}-\bar{x}}{2 \bar{V}_{f \infty}}\right)^{3}} .
$$

$$
\bar{V}=\frac{\bar{V}_{f \infty}}{\left(1+\frac{\bar{x}_{f}-\bar{x}}{2 \bar{V}_{f \infty}}\right)^{2}}+C .
$$

The integration constant $C=-\frac{\bar{V}_{f \infty}}{\left(1+\bar{x}_{f} / 2 \bar{V}_{f \infty}\right)^{2}}$ is defined using the boundary conditions at the beginning of the pipe: $\bar{x}_{i n}=0 ; \bar{V}_{i n}=0$.

The final dependence, which describes the relative velocity variation along the length of the collecting drainage pipeline, will take the form:

$$
\bar{V}=\bar{V}_{f \infty}\left[\frac{1}{\left(1+\frac{\bar{x}_{f}-\bar{x}}{2 \bar{V}_{f \infty}}\right)^{2}}-\frac{1}{\left(1+\frac{\bar{x}_{f}}{2 \bar{V}_{f \infty}}\right)^{2}}\right]=\bar{V}_{f \infty}\left[\frac{1}{\left(1+\frac{1-x / l}{4 A \bar{V}_{f \infty}}\right)^{2}}-\frac{1}{\left(1+\frac{1}{4 A \bar{V}_{f \infty}}\right)^{2}}\right] .
$$

Hence, the relative velocity in the final cross section of the collector will be:

$$
\bar{V}_{f}=\bar{V}_{f \infty}\left[1-\frac{1}{\left(1+\frac{\bar{x}_{f}}{2 \bar{V}_{f \infty}}\right)^{2}}\right]=\bar{V}_{f \infty}\left[1-\frac{1}{\left(1+\frac{1}{4 A \bar{V}_{f \infty}}\right)^{2}}\right] \text {. }
$$

The corresponding graph is shown in Fig. 2.

Analysis of the dependence (21) and the graph in Fig. 2 shows that the relative velocity in the final cross section of the real collecting drainage pipeline $\bar{V}_{f}$ is less than the maximum possible. Moreover, the larger value of the generalized parameter $A$ corresponds to the smaller value of the relative final velocity $\bar{V}_{f \infty}$. Namely, at higher values of $A$, the collecting drainage pipeline will have less capacity and will be able to collect less water through its side surface. 


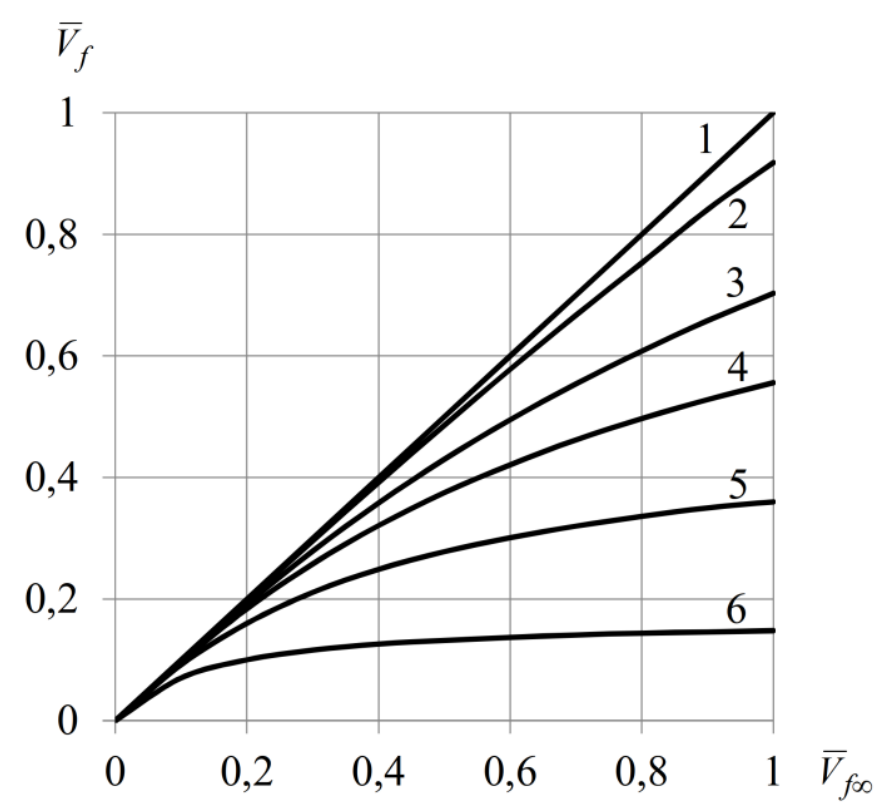

Fig. 2. The ratio between the relative velocity in the final cross section of the conditional infinitely long pipelines $\bar{V}_{f \infty}$ and real pipelines $\bar{V}_{f}$ :

$$
1-A=0 ; 2-A=0.1 ; 3-A=0.3 ; 4-A=0.5 ; 5-A=1.0 ; 6-A=3
$$

The pattern of the variation in the ratio of the average relative velocity to the relative velocity in the final cross section $\left(\bar{V} / \bar{V}_{f}\right)$ along the length of the collecting drainage pipeline $x / l$ (dependence 20) is shown in Fig. 3.

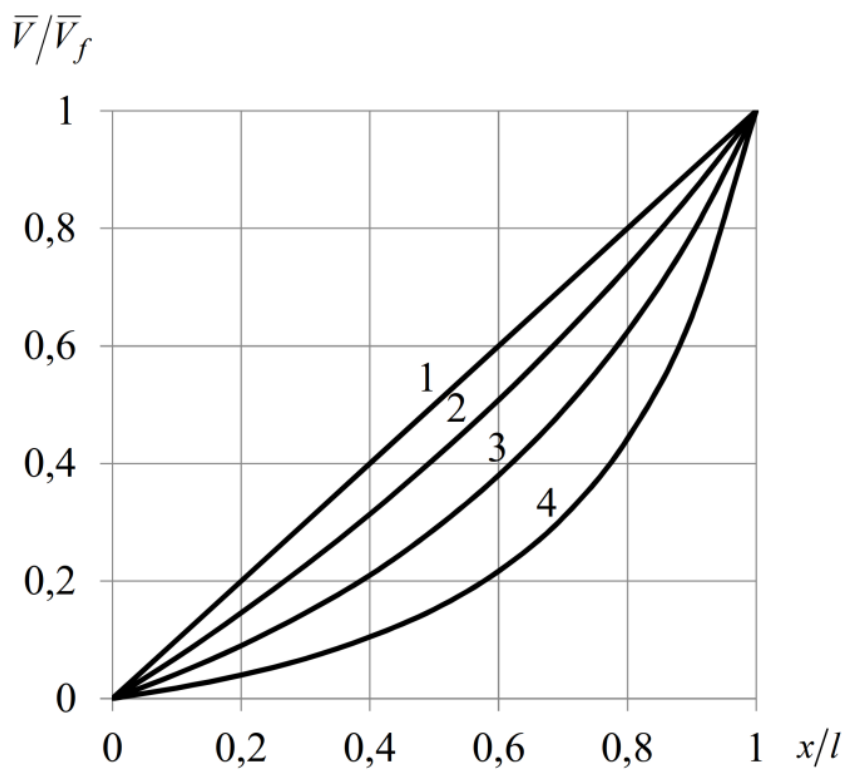

Fig. 3. Graphs of relative velocity variation along the length of the collecting drainage pipeline:

1 - uniform collection; $2-k=1.0 \mathrm{~m} /$ day; $3-k=5.0 \mathrm{~m} /$ day; $4-k=20.0 \mathrm{~m} /$ day

The calculations were performed at three values of the soil hydraulic conductivity, which the drainage pipe was laid in. An intensive and uneven filtration along the pipeline length takes place at $k=20.0 \mathrm{~m} /$ day (curve 4); weak and relatively uniform filtration takes place at $k=1.0 \mathrm{~m} /$ day (curve 2 ); an intermediate value takes place at $k=5.0 \mathrm{~m} /$ day (curve 3 ). For comparison, line 1 characterizes the uniform fluid inflow along the entire pipe length. In all calculations it is conditionally assumed that the drainage pipe is perfect. 
Cases of curves 1, 2 occur only for poorly filtering soils, when the nature of water inflow along the drain is close to uniform. The non-uniformity of the inflow into the collector increases and the discrepancy between the presented curves expands as the filtration properties of the "soildrain" system increase (decrease in the generalized parameter $A$ or the same as the filtration resistance $\bar{\Phi}$ ). Moreover, it becomes maximum in the final cross-sections, where the main water inflow takes place. The above graphs show that a relatively uniform water inflow to the drainage pipeline occurs only in poorly filtering soils. In other cases, the uneven water inflow along the pipeline length increases with filtration intensity growth and it must be taken into account when calculating these systems.

Conclusions. In this paper relatively simple and easy to use calculation dependences are proposed on the basis of the analysis of differential equations describing the fluid motion in horizontal pressure collecting drainage pipelines. The obtained calculated data satisfactorily describe the existing field data. The concept of infinitely long pipeline or pipeline with infinitely large wall filtration capacity was introduced and used in the analysis. It is estimated at which values of the hydraulic conductivity it is necessary to take into account the unevenness of the liquid connection along the pipeline length. The presented formulas are recommended to be applied at various size of filtration characteristics of pipeline walls material and surrounding soil. I consider that it is necessary to study in more detail the internal flow hydrodynamics in collecting drainage pipelines for the further development of this issue.

\section{References}

[1] A. Gramlich, S. Stoll, C. Stamm, P. Walker, V. Prasuhn, "Effects of artificial land drainage on hydrology, nutrient and pesticide fluxes from agricultural fields - A review", Agriculture, Ecosystems \& Environment, vol. 266, pp. 84-99, 2018. doi.org/10.1016/j.agee.2018.04.005

[2] O.Ya. Oleynik, V.L. Poliakov, Drenazh pereuvlazhnennyih zemel. Kiev: Naukova dumka, 1987.

[3] V.V. Cherniuk, V.V. Ivaniv, M.B. Tsenyuh, "Dependence of non-uniformity of water inflow into pressure pipeline-collector on the angle of inflowing jets", Scientific Bulletin of $U N F U$, vol. 29, no. 9, pp. 116-120, 2019. doi.org/10.36930/40290920

[4] G.A. Petrov, Gidravlika peremennoy massyi. Kharkov: Izdatelstvo Kharkovskogo universiteta, 1964.

[5] A.V. Bezusyak, A.F. Dmitriev, N.G. Pivovar, "Gidravlicheskiy raschet kollektorovraspredeliteley", Melioratsiya $i$ vodnoe hozyaystvo, no. 67, pp. 52-59, 1987.

[6] V.O. Mayboroda, "Gidravlicheskiy raschet dren i kollektorov zakryityih osushitelnouvlazhnitelnyih sistem", Gidravlika i gidrotehnika, no. 41, pp. 16-19, 1985.

[7] A.I. Murashko, V.T. Klimov, U.G. Sapozhnikov, Ukazaniya po filtratsionnyim raschetam gorizontalnogo trubchatogo drenazha. Minsk: BelNIIMiVH, 1977.

[8] A.M. Kravchuk, O.A. Kravchuk, Specialni pytannya gidravliky system vodopostachannya $i$ vodovidvedennya: Navch. posibnyk. Kyiv: KNUCA, 2020.

[9] A. Kravchuk, G. Kochetov, O. Kravchuk, "Pipelines designing for steady water collection along the path", Problems of Water supply, Sewerage and Hydraulics, no. 33, pp. 34-40, 2020. doi.org/10.32347/2524-0021.2020.34.19-24

[10] A. Kravchuk, G. Kochetov, O. Kravchuk, "Improving the calculation of collecting perforated pipelines for water treatment structures", Eastern-European Journal of Enterprise Technologies, vol. 6, no. 10(108), pp. 23-28, 2020. doi.org/10.15587/17294061.2020.216366. 
[11] O. Kravchuk, O. Kravchuk, "Evaluation of the impact of different head loss types on the collecting pipelines working characteristics", Problems of Water supply, Sewerage and Hydraulics, no. 34, pp. 19-24, 2020. doi.org/10.32347/2524-0021.2020.34.19-24

[12] G.B. Dvayt, Tablitsyi integralov $i$ drugie matematicheskie formulyi, Perevod s angliyskogo N.V. Levi pod redaktsiey K.A. Semendyaeva. Moskva: Nauka, 1977.

\title{
ОСОБЛИВОСТІ ГІДРАВЛІЧНОГО РОЗРАХУНКУ ЗБІРНИХ НАПІРНИХ ДРЕНАЖНИХ ТРУБОПРОВОДІВ
}

\author{
Кравчук О.А., к.т.н., доцент, \\ kravchuk.oa2@knuba.edu.ua, ORCID: 0000-0001-6578-8896 \\ Київський національний університет будівництва і архітектури \\ пр. Повітрофлотський, 31, м. Київ, 03037, Україна
}

\begin{abstract}
Анотація. Розглянуто систему 3 двох диференційних рівнянь, за допомогою яких описують рух рідини в трубі зі змінною витратою та умови надходження рідини 3 оточуючого грунту через стінки дренажних трубопроводів. Показано, що для даного випадку, другим членом у вихідному рівнянні без суттєвої похибки можна знехтувати. Шляхом введення оригінальних змінних дана система зводиться до безрозмірного вигляду. Наведено розв'язок даної системи рівнянь в безрозмірній формі.

При аналізі були використані два основні параметри: коефіцієнт опору збірного дренажного трубопроводу “ $l_{l}$ ” і узагальнений параметр “ $A$ ”, які комплексно враховують конструктивні та гідравлічні характеристики розглядуваного перерізу. Також в роботі введено поняття нескінченно довгого дренажного трубопроводу або, що те ж саме, трубопроводу 3 нескінченною фільтраційною здатністю стінок дренажного трубопроводу. Відмічається, що такий трубопровід буде мати максимальну пропускну здатність в порівнянні з трубами такого ж діаметра, але обмеженої довжини. На основі проведеного аналізу отримані достатньо прості і зручні розрахункові залежності для визначення характеру зміни витрати і перепаду напорів за довжиною трубопроводу.

За запропонованими формулами проведено серію розрахунків важливих характеристик даних труб і для наочності побудовані відповідні графічні залежності. В тому числі представлено графіки зміни величини витрати в кінці збірника в залежності від конструктивних і фільтраційних характеристик системи “грунт-дрена". Важливим для розуміння особливостей роботи дренажних труб $є$ також графік, на якому приведена залежність зміни нерівномірності приєднання витрати за довжиною дренажного трубопроводу при різних величинах коефіцієнта фільтрації оточуючого грунту. Показано, що для отримання надійних результатів при розрахунку реальних дренажних трубопроводів обов'язково необхідно враховувати характер нерівномірності приєднання витрати за довжиною таких каналів.
\end{abstract}

Ключові слова: збірний трубопровід, дренажний трубопровід, гідравлічний коефіцієнт тертя, коефіцієнт фільтрації, фільтраційний опір, дрена, змінна витрата рідини. 


\title{
ОСОБЕННОСТИ ГИДРАВЛИЧЕСКОГО РАСЧЕТА СБОРНЫХ НАПОРНЫХ ДРЕНАЖНЫХ ТРУБОПРОВОДОВ
}

\author{
Кравчук А.А., к.т.н., доцент, \\ kravchuk.oa2@knuba.edu.ua, ORCID: 0000-0001-6578-8896 \\ Киевский национальный университет строительства и архитектуры \\ пр. Воздухофлотский, 31, г. Киев, 03037, Украина
}

\begin{abstract}
Аннотация. Рассмотрена система из двух дифференциальных уравнений при помощи которых описывают движение жидкости в трубе с переменным расходом и условия входа жидкости из окружающего грунта в через стенки дренажных трубопроводов. Показано, что для данного случая, вторым членом в исходном уравнении без существенной погрешности можно пренебречь. Путем введения оригинальных переменных данная система приводится к безразмерному виду. Приведено решение данной системы уравнений в безразмерном виде.

При анализе использованы два основных параметра: коэффициент сопротивления сборного дренажного трубопровода “乌”, и обобщенный параметр “ $A$ ”, которые комплексно учитывают конструктивные и гидравлические характеристики рассматриваемого течения. Также в роботе введено понятие бесконечно длинного дренажного трубопровода или, что тоже самое, трубопровода с бесконечной фильтрационной способностью стенок дренажного трубопровода. Отмечается, что такой трубопровод будет иметь максимальную пропускную способность по сравнению с трубами того же диаметра но ограниченной длины. На основании проведенного анализа получены достаточно простые и удобные расчетные зависимости для определения характера изменения расхода и перепада напоров по длине трубопровода.

По предложенным формулам проведена серия расчетов важных характеристик данных труб и для наглядности построены соответствующие графические зависимости. В том числе представлены графики изменения величины расхода в конце сборника в зависимости от конструктивных и фильтрационных характеристик системы “грунт-дрена”. Важным для понимания особенностей работы дренажных труб есть также график на котором приведена зависимость изменения неравномерности присоединения расхода по длине дренажного трубопровода при различных величинах коэффициента фильтрации окружающего грунта. Показано, что для получения надежных результатов при расчете реальных дренажных трубопроводов обязательно необходимо учитывать характер неравномерности присоединения расхода по длине таких каналов.
\end{abstract}

Ключевые слова: сборный трубопровод, дренажный трубопровод, гидравлический коэффициент трения, коэффициент фильтрации, фильтрационное сопротивление, дрена, переменный расход жидкости.

Стаття надійшла до редакції 26.04.2021 